\title{
Linguistic Transfer and its Effects on Secondary Stage Students' Translation
}

\author{
Dr. Randa M. Safyeddin Kharboush. \\ Lecturer of Curriculum\& EFL Instruction Faculty of Education, \\ Benha University
}

\section{$\underline{\text { Abstract }}$}

The purpose of this study is to show through the interference of the native language, Arabic, in the English translation of the Egyptian students. It aims at probing some discrepancies in the Egyptian secondary stage students' proficiency in translation, attributed to lexical and semantic transfer from Arabic to English, reflected through a set of language tasks. The participants are 35 Egyptian secondary stage EFL students; studying English as part of their curriculum, during the second semester of the school year 2015-2016. The study raises the question: What problems arise from the linguistic of Arabic when translating different written texts into English and conversely? To achieve the goal of the study, the researcher analyzed the participants' errors in written translation texts. Since the study is mainly qualitative; some kinds of transfer/interference phenomena that occurred in the collected data were spotted, the possible communicative strategies that the participants employed, consciously or unconsciously, when translating were identified and exemplified and the reasons behind their occurrence were analyzed. Besides, a quantitative analysis was carried out to interpret the results using frequencies and percentages. Results showed that the problems that arise from interference are mainly lexical and semantic, and might be attributed to the participants' lack of knowledge and awareness of the source language as well as the target one. The study concluded that sometimes translations from Arabic into English and vice versa tend to lose original meanings or be misinterpreted compared to the source text because of linguistic transfer. It is suggested that raising awareness of liguistic transfer through focused attention on transfer errors alongside with systematic instruction and practice on translation might be valued by the students and seemed essential for them to achieve productive proficiency.

Keywords: Linguistic transfer, interference, translation, Arabic (native language), English (target language)

\section{نقل اللغويات وآثارها على ترجمة طلاب المرحلة الثانوية}
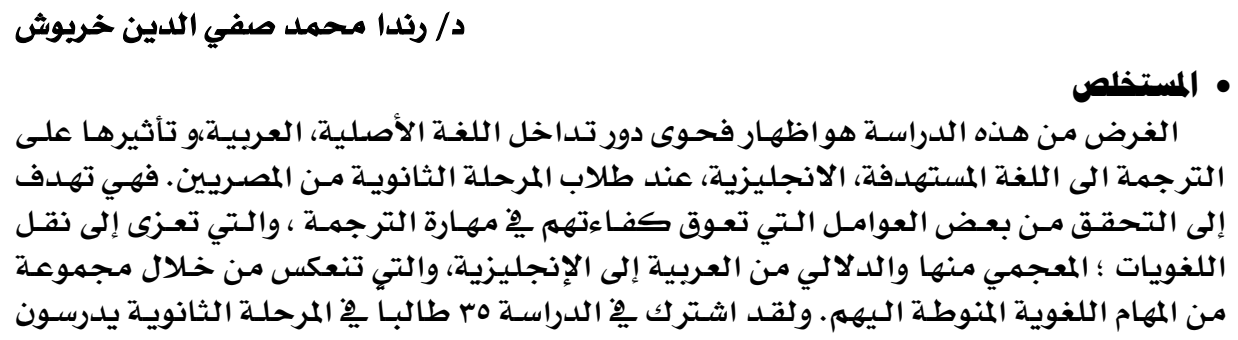


\section{Number 73, Part 2, May, 2016}

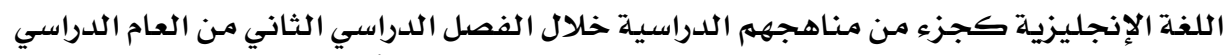

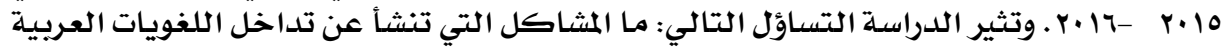

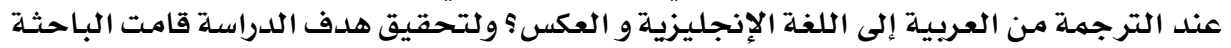

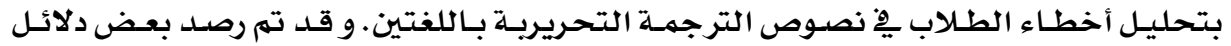

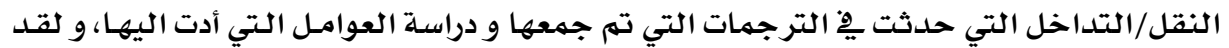

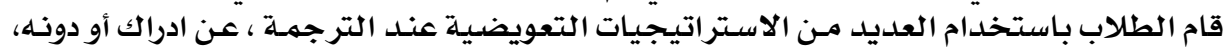

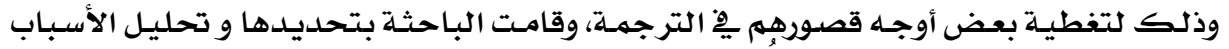

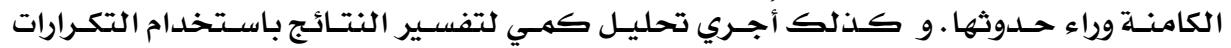

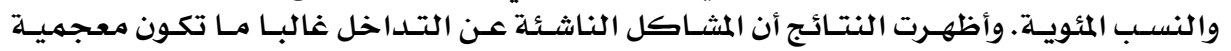

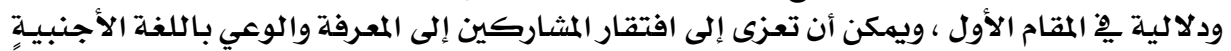

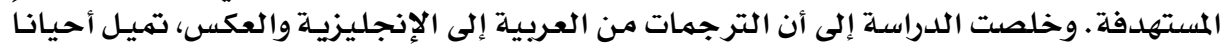

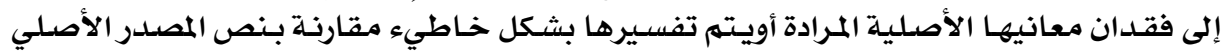

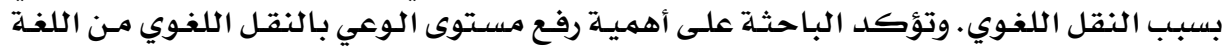

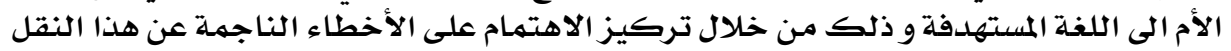

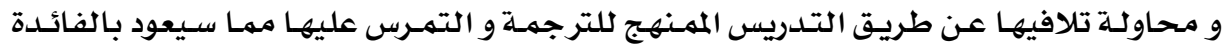

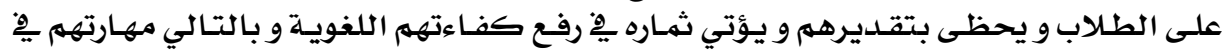
الترجمـة.

الكلمات المفتاحية: نقل اللغويات، تداخل، ترجمة، العربية (اللغة الأصلية)، الإنجليزية (اللغـة

المستهلماتة)

\section{- Introduction}

Languages are used by people throughout history to communicate and establish relationships, and since people use and learn different languages, contact is ought to occur and mistakes emerge. The question of whether the native language/first language (NL / L1 hereafter used alternatively) has any effects on foreign/second language or target language (TL/L2 / FL hereafter used alternatively) performancel proficiency has attracted the curiosity of numerous linguists as well as language educators and led to a significant number of studies being conducted on the issue.

Many of them have revealed a connection between NL transfer and errors in TL production. The difference between one language and the other leads to interference (Norish, 1992 and SattiHamad\& Yassin 2015). It has long been acknowledged that a learner's NL has a considerable influence on both the acquisition and use of TL vocabulary (Swan, 1997). This influence often manifests itself in lexical errors in oral and written production which are seemingly difficult for the learner to eliminate. The fossilization of erroneous lexical forms is especially likely when learners are in a monolingual educational environment, like Egypt, as much of their exposure to English comes from other language learners; i.e., the teachers, who share the same $N L$, so that the same errors are reinforced and normalized. As a consequence, teachers may give too little attention in class to dealing

\section{4}




\section{Number 73, Part 2, May, 2016}

with these errors and to raising awareness amongst learners of how NL can help or hinder accurate vocabulary use.

Every foreign language teacher has had experience with interference. Interference is the negative influence of $N L$ on the performance of the TL (Lado, 1964). Research on second language acquisition has long acknowledged the important role of this linguistic influence, which results in language transfer. According to Oldin (1989), "Transfer is the influence resulting from similarities and differences between the target language and any other language that has been previously acquired." Previous studies have been carried out on the different perspectives of transfer such as the transfer of rhetorical redundancy (Bartlet, 1983), the transfer of absolutes (Oldin, 1992), pragmatic transfer (Kasper, 1992), and the transfer of textual organization (Fakhri, 1994). Many researchers, starting with Mehdi 1981, going through Al-Najjar 1984, Mouakket 1986, Farghal 1995, Diab 1996, Bhela 1999, Jiang 2004, Ben-Osman 2005, Ellis 2006, Ali 2007, Bahameed 2008, AbiSamara 2009, Havlaskova 2010, and ending with Erarslan \& Hol 2014, have found that the contact between a NL and a FL may result in many deviations in the latter, such as syntactic/grammatical interference, lexical/semantic interference and pragmatic interference. Such deviations or interference cases are often caused by transfer from the NL to the TL. Transfer may be either positive or negative transfer. The positive transfer facilitates the communication in the $T L$, whereas the negative one may lead to making errors in the FL (Benson, 2002). These deviations resulting from the contact of NL with TL are commonly discussed in terms of linguistic interference (Oksaar, 1963), including its concepts and categories. For instance, boyfriend or girlfriend in Sweden is a steady partner one may live with as if one were married, and someone one might have children with, whereas in Brazil, these terms do not imply much commitment, until one is engaged and married. Thus, different perceptions about the world facilitate positive or negative transfer between L1 and L2 (Cruse, 2004). Different languages may have different mental concepts and categories, such as the way different cultures are interpreted.

Translation plays a significant role in ELT; it was an essential part of it for a long time and then a considerable missing part for a long time. Translation abandoned activities are now a feature of many communicative classrooms and successful aids to learning, although the approach to using them has changed. Teachers and students now use translation to learn, rather than learning translation. Modern translation activities usually move from NT to TL and conversely, have clear communicative aims and real cognitive depth. However, learning translation is not an easy process, because learners may be faced by

\section{5}

Journal of Arabic Studies in Fd!Ication \& Psychology (ASEP) 


\section{Number 73, Part 2, May, 2016}

some problems, one of them is language interference. Havlaskova (2010) claims that interference is a universal phenomenon, that occurs very often in students' translations. Hopkinson also asserts that "the issue of linguistic interference is a factor in any translation, and when the translator is working from L1 into L2 interference from the L1 source text becomes a key element in the production of the L2 target text" (Hopkinson, 2007). As claimed by Pyme\& Gutierrez (2013), translation is inherent in language learning, and would be considered a fifth skill to be practiced within language classroom, alongside with listening, speaking, reading, and writing in the two languages independently. On this view, translation is a way (or a set of ways) of learning a foreign language and it can function as an impediment to effective language learning. Al-Najjar (1984) argued that the issue of translatability is believed to be translator-dependent. Using his skill and experience, the competent translator can translate the untranslatable and creatively offer somewhat meaningful TL versions out of the most obscure texts.

Interference, as described by Havlaskova (2010), is a phenomenon that may occur at the level of a word, a phrase, an idiom, a metaphor or a term of a whole syntactic structure when translators transfer some source texts into target texts influenced by different aspects of the source language. The current researcher has dealt with lexical transfer at the level of a word, the verb 'كسر' 'kasara' 'broke', and the level of lexicons, a set of 10 lexical units. As long as the term transfer or interference is seen as the influence of the NL on the learning of the TL and the transfer that occurs, then interference errors can be clearly seen in translation. The widespread notion of translation may lead to the appearance of those errors. Errors are usually seen in written translation especially in lexicon, syntax and semantics and most of them are triggered by the interference of the NL, and its influence which occurs naturally, and sometimes subconsciously.

As a matter of fact, a review of the related literature written on transfer indicates the need for more research in the area of translation. However, dealing with translation in our educational system is problematic and still having many challenges to face by both teachers and EFL learners. One of the obstacles encountered by teachers and learners is language transfer or interference. Linguistic interference refers to learners applying knowledge from their NL (Arabic) to the TL (English), including EFL secondary school students in Egypt.

\section{- Statement of the Problem}

In Egypt, secondary stage students for whom English is an integral part of their curriculum often need to achieve a high level of linguistic

\section{6}




\section{Number 73, Part 2, May, 2016}

competence and accuracy, which means that basic vocabulary errors need to be minimized, or if possible eliminated. Besides, the inadequate teaching methods and the delinquency in training the secondary stage students on how to produce proper translation, especially the guided ones, with native-like English lexicons have lessened their chances to practice translation and to achieve the required level of proficiency.

Therefore, the researcher perceived a clear need for this issue to be addressed in some way in such a context, although there has been considerable research on the effect of $N L$ influence on TL, little has been written about how to approach the problem of negative lexical transfer in translation in EFL the classroom in Egypt.

Hence, the present study posed the following main question: What problems arise from the linguistic transfer/interference of Arabic when translating different written texts into English and conversely?

The following sub questions emerged from the main one:

a. What type of linguistic transfer, if any, is frequently found in the secondary stage students' translation?

$b$. What are the factors that contribute to the occurrence of this transfer in translation?

c. To what extent does linguistic transfer affect translation?

\section{- Scope}

This study is delimited to the translation of written texts due to the easiness of handling written sources and because it seems to be more useful for the secondary school students, either to avoid linguistic interference occurrences or to improve the comprehensibility of the translated texts.

\section{- Theoretical Background}

The similarities and differences between the NL and the TL lead to transfer or interference. According to Jie 2008, transfer is "the carrying - over of learned responses from one type of situation to another". Transfer can be of two types: positive transfer and negative transfer. The positive transfer refers to the process of using rules from $N L$ which facilitates or has a positive influence on learning TL. This transfer is mostly due to similarities between NL and TL. In contrast, negative transfer is the transfer of rules from NL which impedes or has harmful influence on the command of rules of TL, which due to differences between the two languages.

The review of literature provides a bulk of previous studies that have been traced and analyzed according to their findings to find differences between Arabic as a NL and English as the TL that causes Arab learners of English to make mistakes. Many studies and researchers;

\section{7}

Journal of Arabic Studies in Ed!Ication \& Psychology (ASEP) 


\section{Number 73, Part 2, May, 2016}

Mehdi 1981, Al-Najjar 1984, Mouakket 1986, Farghal 1995, Diab 1996, Bhela 1999, Jiang 2004, Ben-Osman 2005, Ellis 2006, Ali 2007, Bahameed 2008, AbiSamara 2009, Havlaskova 2010, Erarslan \& Hol 2014, have found that the contact between a NL and a FL may result in many deviations in the latter, such as syntactic/grammatical interference, lexical/semantic interference and pragmatic interference. These deviations are commonly discussed in terms of linguistic interference, also known as cross-linguistic influence or lexical transfer.

Brown (2007) defines transfer as the influence which occurs between $N L$ and TL because of the similarities and differences between them. He also adds that transfer is viewed as the interaction between pervious linguistic knowledge and present learning process which facilitate the new learning task. Similarly, Mitchell and Myles (2004) state that this transfer is also known as cross- linguistic interference and that is the speakers' or writers' knowledge of their NL is used as a way to acquire $T L$.

\section{- Linguistic transfer}

'Linguistic transfer' or 'cross-linguistic influence' is defined as 'the influence that a person's knowledge of one language has on that person's recognition, interpretation, processing, storage and production of words in another language" (Jarvis, 2009). To a great extent, lexical transfer has an effect on the different dimensions of word knowledge including word recognition as in the receptive tasks, and its use as in the productive tasks. In the case of translation, this constitutes a penultimate obstacle. Research on linguistic; lexical and semantic, transfer is concerned with how different dimensions of word knowledge; form, meaning and use, relate to one another in the mind, and how lexical transfer operates in the minds of learners. Jarvis (2009) distinguishes between two broad types of lexical transfer: the lemmatic transfer and lexemic transfer. The scope of lexemic transfer contains both the graphemic and phonological structure of a certain form of a word (Jarvis, 2009). Many researchers' main concern was the syntactic kind of transfer, (e.g., Mehdi, 1981, Zreg, 1983, Mouakket, 1986, and Ben-Osman, 2005). On the other hand, the lemmatic transfer scope relates to the semantic (e.g. polysemy, synonymy, antonymy, etc.) and word properties. Translation encompasses both syntactic and semantic specifications simultaneously; hence, it is a part of the lemmatic transfer.

The consequences of lexical transfer, whether lemmatic or lexemic, can be seen in learners' faulty and erroneous language use. According to Jarvis (2009), this negative transfer generally occurs through one of the two mental processes in the learner mental lexicon: (1) the

\section{8}




\section{Number 73, Part 2, May, 2016}

construction of learned cross- linguistic associations and (2) processing interference. Learned cross-linguistic associations involve formed mental links between stored representations of words from the two languages; NL and TL. In contrast, processing interference could take place through the activation of words in one language when the speaker or writer is trying to use another language. However, Jarvis (2009) credibly argues that none of the types of lemmatic transfer (including translational transfer) seem to be induced to any significant degree by processing interference or activation levels. Instead all types of lemmatic transfer seem to result mainly from the ways that FL users construct lexical representations in one language in accordance with their knowledge of corresponding words in another language. During the early stages of FL acquisition, words in the TL are assumed to be linked to their translation equivalents. The activation of the translation equivalent in NL facilitates access to meaning for the new TL words, because words in the NL are hypothesized to correspond directly to their equivalents in the TL (Sunderman \& Kroll, 2006). In the FL learning classroom, $N L$ and TL lexical development processes differ significantly due to two practical constraints that NL acquisition is not subject to. The first constraint is the lack of sufficient input in terms of quality and quantity. The second constraint in FL learning is the existence of an established semanticl conceptual system with an NL lexical system closely associated with it. Because of the presence of the established NL lexical system, FL learners may rely on that system to learn new words in TL (Jiang, 2000).

\section{- Lexical Errors}

Abi Samara (2003) listed some examples on lexical errors made by Lebanese students in their writing. Due to literal translation from Arabic, students might use "stay on" instead of "continue" or "keep on"; they might use inappropriate equivalent. The following are some examples of lexical errors.

Table 1

\begin{tabular}{|c|c|c|}
\hline Arabic $\Rightarrow$ & Incorrect $\Rightarrow \underset{\text { right health. }}{\text { He has a }}$ & Correct $\rightarrow \mathrm{He}$ is healthy. \\
\hline & Incorrect $\Rightarrow \underset{\text { Strong disease }}{\text { He }}$ & $\begin{array}{l}\text { Correct } \Rightarrow \text { He has a } \\
\text { severe illness. }\end{array}$ \\
\hline الأصوات العائية & $\begin{array}{r}\text { Incorrect } \rightarrow \text { I am afraid } \\
\text { from high sounds. }\end{array}$ & $\begin{array}{l}\text { Correct } \rightarrow \text { I am afraid of } \\
\text { high sounds }\end{array}$ \\
\hline
\end{tabular}

Certain words that have distinctive meanings in English, like 'special' and 'private' have only one equivalent in Arabic 'خاصسة'. Students, therefore, are likely to say: "My brother went to a special hospital." Or "This is a very private occasion." Also, there is the sentence "He cut the street", to be the translation for the Arabic expression قطع الثارع which is used instead of "He crossed the street".

\section{9}




\section{Number 73, Part 2, May, 2016}

\section{- Translation}

Translation was a significant part of ELT for a long time, and then a significant missing part for a long time also. It was the basis of language teaching for a very long time, and then rejected as new methodologies started to appear. With the arrival and then total dominance of communicative methodologies, translation was quickly consigned to the past, along with other 'traditional' tools such as dictation, reading aloud and drills. However, it and these other abandoned activities are now a feature of many communicative classrooms and successful aids to learning, although the approach to using them has changed. As Duff (1989) says, teachers and students now use translation to learn, rather than learning translation. Modern translation activities usually move from L1 to L2, (although the opposite direction can also be seen in lessons with more specific aims), have clear communicative aims and real cognitive depth, show high motivation levels and can produce impressive communicative results.

Translation, as the fifth language skill, in the language classroom represents an essential element of students' linguistic and communicative competence that prepares them for real-life situations in their studies and future jobs (Naimushin, 2002). Translation is defined as "the process of translating words or text from one language into another; and the written or spoken rendering of the meaning of a word, speech, book or other text, in another language" (Stevenson, 2003). The ability to produce an accurate and correct translation from/to a second/foreign language constitutes a challenge to student translators for two reasons. First, translation teaching has a complex nature, which requires more dynamic pedagogical methods ( $\mathrm{Li}, 2006)$. Second, many approaches to teaching translation require more flexibility and adaptability to students' needs and building bridges between language teaching and translation pedagogy (Carreres, 2006). Newmark (1988) describes translation as rendering and transferring meaning from the native language into the target language as it is intended by the original writer. Similarly, Gaber (2005) adds that the aim of translation is to communicate ideas of the text in the source language to the readers of the target language. Accordingly, the reader of the target text will read the text as if it is written in the target language believing that the text contains the source language writer's true intentions. While translating from one language to another, there is a room for transfer to occur.

However, for a considerable period of time and across different educational contexts and countries, translation was one of the key tools for teaching and assessing language competence, including vocabulary. Over time and with the emergence of different language teaching 


\section{Number 73, Part 2, May, 2016}

approaches, the use of translation as a teaching and assessment tool has gradually declined (Tsagari \& Floros, 2013). The reasons for this decline were mainly related to: (1) false perceptions of the notion of translatability in connection with language pedagogy; (2) the equally false interpretations of the translation task as a common attempt to utilize a grammar-translation method for teaching a language; and (3) the insufficient attempt from translation studies to consider ways of informing other areas of language-related activity (Tsagari \& Floros, 2013). However, translation is re-emerging as an important tool that serves the various purposes of language teaching and assessment.

In relation to the lexical domain and vocabulary teaching and learning, translation has long been classified as part of the 'social strategies' to learning vocabulary, as classified by Schmitt, 1997, in which the teacher is the source of information including translation in L1. It is considered to be the simplest way of providing definition and communicating word meanings (Nation, 2001). Moreover, the examination of words in a range of contexts and uses through translations, concordances or dictionaries is considered a part of rich instruction which involves learning the meanings, comparing and contrasting words, etc. (Nation, 2001). Translation tasks were also widely used in numerous studies as an assessment tool providing evidence of the learners' receptive and productive vocabulary knowledge. They have been proven to activate different aspects and levels of language processing, such as awareness of similarities and differences between L1 and L2, distinguishing patterns in each language, increasing positive transferability, and enhancing mental flexibility and memorization (Belpoliti \& Plascencia-Vela, 2013; Goundareva, 2011; Laufer \& Girsai, 2008a, b; Machida, 2008).

It is of paramount importance to note that translation tasks are used in this research as a tool that is well established in the literature of vocabulary teaching and assessment. Most relevant for this research, the translation tasks are intended to be utilized as an instrument to emphasize and raise learners' awareness of a presumed automatic mental process that takes place in the bilingual mental lexicon (i.e. lexical transfer), and to conduct self-initiated lexical contrastive analysis. In fact, James (1996) points out that translation is a predominantly effective way to raise cross-linguistic awareness since "uniquely, in the act of translation two manifestations of NL and FL are juxtaposed and language juxtaposition is the very essence of contrastive analysis". The present study is limited to the process of translating words or texts from Arabic into English and vice versa, by secondary school students, to assess the lexical transfer between the two languages. 


\section{Number 73, Part 2, May, 2016}

\section{- Review of Previous Related Studies}

Havlaskova (2010) analyzed interference in students' translations, from English into Czech. The researcher used a translation test which consisted of six texts that were assigned to the students for translation in the two courses; cultivating translation skills and text and discourse analysis as weekly homework, three texts each course. Seventy-seven translations were analyzed presented in tables. A questionnaire asking students about their views of interference was conducted. They completed it anonymously and on the spot. The questionnaire included 18 questions inquiring the students' awareness and perception of interference. The first 4 questions were general asking for students' demographic information. Questions from 5-17 asked about students' perception of interference and the last question challenged them to express their suggestions and observations concerning the topic. The results showed that there were many types of interference found in students' translations such as lexical, syntactic, grammatical and typographical. The results from the analysis of students' translations showed that lexical and syntactic interferences occurred with the greatest frequency. Nevertheless, according to the answers from the questionnaires $74 \%$ of students considered syntactic interference the most frequent type. On the other hand, lexical interference was in their opinions the most serious one. According to the analysis of both instruments it was concluded that although students may be aware of the influence of interference, it would still cause the many difficulties especially when they occur on the level of syntax and lexis.

Vannestal (2009) explains that interference is the contact which takes place between a native and a foreign language. This interference may cause deviations in the target language like syntactic, grammatical, lexical, semantic or pragmatic which were the most frequent causes of interference. In a case study of Portuguese interference in abstracts translated into English (Galvao, 2009), the researcher deals with linguistic interference in abstracts of scientific papers translated from Portuguese into English. The aim of this study is to analyze linguistic interference phenomena in 50 abstracts from the field of humanities, history, social sciences, technology and natural sciences. The types of interference discussed are syntactic/grammatical, lexical/semantic and pragmatic interference. The results showed that interference could be found more frequently in the translations of humanities, social sciences and history than technological and natural sciences. She states that lack of clarity or understanding from NL to TL has shown to be one of the main reasons for the problems in translation. Although the syntactic structure of the statements is important, partial transfer of information is noticed in the translations of less than advanced learners.

\section{2}

Journal of Arabic Studies in Education \& Psychology (ASEP) 


\section{Number 73, Part 2, May, 2016}

Maros, Hua and Salehuddin (2007) dealt with interference and its effect on TL learning in Malaysian secondary schools. The researchers followed Norrish's (1992) approach in conducting error analysis and identifying, describing, explaining and evaluating errors. The sample was chosen from six different local schools and the students' written essays were analyzed. The results showed that despite having gone through six years of learning English in schools, the learners were still having difficulties in using correct English grammar in their writings. The three most frequent errors made by the students were in grammar, and the most frequent ones were the use of articles, subject-verb agreement and copula 'to be'. With more limitations, Bloem, Bogaard \& La Heij (2004) investigated semantic interference which was found in word- translation. A group of 26 university students who were native speakers of Dutch and highly proficient in English participated in the experiments that included 32 high frequency English words which were familiar to the Dutch students. The results showed that semantic interference was found at the lexical level and there were clear indications of the influence of NL on TL.

SattiHamad and Yassin (2015) investigated lexical errors and their effect on university students' writings. The researchers used a descriptive analytical approach, and they conducted a questionnaire which was given to 67 university English language teachers from different universities in Sudan. A composition test was given to 150 university students whose NL was Arabic and majored in English from different English departments. They were asked to write an essay about Sudan. The results showed that the lexical errors that occurred were classified as; word choice, transliteration, omission, misspelling and redundancy. These errors were mainly influenced and caused by interference of the mother tongue. There are two sources of errors which are attributed to the learner's NT or his/her TL, i.e. the language he/she intends to learn. Two thirds of errors are attributed to NL interference and one third to intra-English (IL) interference (Bhela, 1999; Ghawi, 1993). If the two languages are drastically different, learners will use the linguistic patterns they have learnt in their NL to help them do tasks in TL. These errors are called the "intralingual/ developmental errors". These are errors caused by some processes that learners recourse to when learning the TL. These include generalization, substitution and other processes.

Dweik (2013) identified the difficulties students faced when translating cultural and literary expressions from English into Arabic. A translation test was developed and semi structured interviews were conducted. The test included an English political text entitled "Power

\section{3}

Journal of Arabic Studies in Education \& Psychology (ASEP) 
needs clear eyes". He used a sample of 20 university English major students. The researcher also conducted interviews which consisted of three questions that aimed to find out the difficulties that students faced in their translations. The results showed that: (a) the students committed many lexical, syntactic and cultural errors due to their lack of awareness and knowledge of the target language and culture; (b) they also misused dictionaries in the process of getting suitable meanings for the words.

Furthermore, Faris and Sahu (2013) found that $70 \%$ of the participants, in an Iraqi university in their senior year at College of Education, encountered difficulties in the translation of English collocations into Arabic. In the current study, the researcher is concerned with the analysis of students' responses to translations task to reveal the problems that the secondary school students encounter while translating. In addition, Thawabteh (2011) indicated in his study that Arab students encounter many linguistic, cultural and technical problems when subtitling from English into Arabic.

In his study of hindrances in Arabic-English intercultural translation Bahameed (2008) compared between the two languages, Arabic and English in terms of syntax, which demonstrate variant structures or word orders. Arabic has a feature of being a synthetic language, in terms of prosody, while both of the two languages have their own versification systems but in terms of phonology and phonemic inventories, they are not the same. Furthermore, when evaluating the actual translation hindrances, the geographical distance cannot be overlooked between Arabic and English from where they are originated and which might lead to a cultural distance between them. Consequently, a classification for the main translation hindrances, which influence the translation quality of the outcome, can be made into: 1) lexical hindrances, 2) prosodic hindrances, 3) structural hindrances, and 4) cultural hindrances.

Diab (1996) has examined lexical, grammatical, syntactic and semantic errors made by Lebanese students. She selected 73 Lebanese native speakers of Arabic taking an intermediate level English course in their sophomore year studying at the American University of Beirut. She analyzed their English writings through error analysis to show the degree of mother tongue (Arabic) interference that occurred in them. As a result of the examination, it was noticed that there was a great influence of the Arabic linguistic structure on the English writings of the students. Therefore, errors were classified into lexical, grammatical, semantic and syntactic. The analysis revealed the existence of 558 grammatical errors which include articles, prepositions and singular 


\section{Number 73, Part 2, May, 2016}

and plural, 217 lexical errors, 106 semantic errors and 193 syntactic errors that included word order, coordination and omission of the copula had occurred in most of the students' writings. Most errors occurred where the students felt that Arabic and English were similar whereas fewer errors were committed where there were clear differences between the two languages. Moreover, Farghal (1995) cited five lexical/discoursal translation problems encountered by Arab postgraduate students, when they translate from English into Arabic: Translation of metaphorical expressions; translation of English phrasal verbs; students' altering of impersonal English pronouns for personal ones; finding formal and functional equivalence of lexical items; and missing the thought relationships between sentences (i.e. addition, contrast, and causeleffect).

It is clear that previous research has shown that Arab students encounter some problems while translating from English into Arabic. For example, the literal translation of the English passive voice sentences from English into Arabic is a common problem (Khalil, 1993). This problem was attributed to the little attention paid to the non-equivalency syntactic structures between Arabic and English and translation procedures. Other research showed that Arab students face some translation problems at the level of syntax, layout and content of the legal texts written in English (Farghal \& Shunnaq, 1992).

To conclude, these translation problems, accredited to linguistic transfer, might be attributed to two reasons: traditional classroom teaching which is often regarded as ineffective and boring; and the deficiency of systematic approaches to the teaching of translation skills. So, it is time to study which linguistic features are transferred from Arabic (NL) into English (TL) when translating as well as the factors affecting that process. This is exactly the purpose of the present research. Perhaps the best way to discover such transfer is through analysis, i.e. analyzing the systematic errors that students make in their translations, from Arabic to English and vice versa, in order to find out which mistakes result from their native Arabic language influence. Needless to say, when the language teacher shares the same mother tongue with his/her students and has been a foreign language learner, distinguishing transfer errors from other kinds of errors becomes much easier. Both the researcher and the participants of the current study have Arabic as their mother tongue and the researcher has once been an EFL student herself. Therefore, as far as this study is concerned, data analysis no longer involved pulling out all types of error and attributing them to their respective sources in order to distinguish transfer errors. These were apparent upon reading the participants'

\section{5}

Journal of Arabic Studies in Fd!Ication \& Psychology (ASEP) 


\section{Number 73, Part 2, May, 2016}

translations. Data analysis, thus, was reduced to categorizing some types of transfer errors made by the participants.

\section{- Method}

The researcher used translation as a form of productive skill and analyzed the participants' translation of written texts as a medium. As EFL learners, secondary stage students face difficulties with conveying the intended meaning in translating written texts from Arabic to English and vice versa. They have difficulty mainly in the production of accurate and acceptable sentences in their translation. These cases seem to corrupt the full understanding of the translations and make them sound unnatural in English.

\section{- Participants}

At the outset of this study, 77 female secondary stage EFL students, at Al-Sadat Secondary School for Girls, Sheblanga, Banha Educational Directorate, Qualyubia Governorate, Egypt, expressed their willingness to participate in the experiment, during the second semester of the school year 2015-2016. Due to their repeated absences throughout the testing administration phase 23 students were excluded. Some other test copies; 19 copies, were removed and disregarded in the data analysis because the responses were incomplete. The remaining 35 participants were second year EFL students at secondary stage, aged between 16-18 years, and had never lived in an English-speaking country. They are homogeneous in the fact that they all speak Arabic as their mother tongue, and they have been studying English in public schools since the first year of elementary stage. Thus, the participants' English backgrounds were similar since they had studied English for at least 12 years and have been exposed to it from an average age of 5-6. Given their educational background, students at this academic level were expected to be mainly between lower and upper intermediate level of English language proficiency.

\section{- Instruments}

\section{- Preliminary Instrument}

The current research was designed to investigate the participants' use of lexical semantics of English in their translation and the effect of lexical transfer from Arabic, as their NL, to English, as the TL, on their translation skills. Prior to using the research tools, it was crucial to make sure that any variation in research results could not be attributed to variations in the participants' English proficiency levels or vocabulary knowledge levels. To address this issue, a commonly used and freely available test was administered to the participants: the Vocabulary Level Test (VLT) by Schmitt, Schmitt and Clapham (2001,

\section{6}




\section{Number 73, Part 2, May, 2016}

version 2). Another reason for the VLT and for making sure that all participants achieved a similar level in lexical coverage and vocabulary knowledge is the fact that the students were required to carry out translation tasks. It was thus necessary to have an insight into whether or not they were likely to have the lexical resources necessary to cope with the translation tasks, both receptively and productively.

\section{- Vocabulary Level Test}

Schmitt, Schmitt and Clapham's (2001) vocabulary level test (K2 and $K 3$, version 2, Appendix 1) was given to the participants. On the K2 test, the group achieved the mean scores of 18.41. On the other hand, they achieved the mean scores of 12.00 on the K3 test.

Table 2. Vocabulary Level Test Descriptive Statistics and Normality test

\begin{tabular}{|c|c|c|c|c|c|c|}
\hline Parameter & $N$ & Mean & Median & $\begin{array}{c}\text { Std. } \\
\text { Deviation }\end{array}$ & Min & Max \\
\hline K2 & 35 & 18.41 & 25 & 6.08 & 1 & 26 \\
\hline K3 & 35 & 12.00 & 19 & 4.04 & 6 & 19 \\
\hline
\end{tabular}

\section{- Research Instruments}

The distinction between passive and active knowledge of vocabulary may not be as simple as it seems, as there exists a great discrepancy in the use and interpretation of active and passive knowledge in the various studies (Read, 2000). In this research, the researcher follows the distinctions of Nation (2001) and Laufer et al. (2004) and refers to the ability to provide a word meaning as passive knowledge and to the ability to provide the word form as active knowledge. In that sense, the ability to supply the translation form of the $T L$ in response to the learners' NL translation equivalents is considered by the researcher as an active recall, and their ability to supply the meaning of the target words as passive recall (Laufer \& Girsai, 2008a, b; Takala, 1984).

Linguistic transfer occurs in various cases, such as simple words and phrase. Lexical interference in the level of simple words relates to false cognate; is a word which has the same or very similar form in two languages, but has a different meaning in each (Richards and Schmidt, 2010). The similarity may cause the foreign language learner to use the word wrongly. To test the lexical transfer on the word level, the researcher used the verb كسر 'kasara' that assumed to mean 'broke' in 16 different collocations included the English translation in a multiple choice test. In the level of phrase, the interference occurs because of reproducing source language phrase to target language. In this case, it relates to word for word translation. A set of the target lexicons were used to test the transfer on the level of phrases in the form of multiple choices, fill in the blanks, and free translation tasks. That set contains 
the following lexical units: open air - key areas - vast majority immediate future - recent years - hard copy-round trip - domestic violence - careful attention - common sense.

- Multiple Choices (MC)

The first form of the test was a multiple choices (MC) task. First, a translation of the sixteen 'كسر 'kasara' 'broke' verb given to the participants to recognize the appropriate collocation from plausible alternatives (Appendix 2). The second (MC) test (Appendix 3) included 10 items, each of which included the target words that were adapted from the E/A parallel corpus. They were also checked against Lextutor for the words' K-levels. Words that did not belong to the K2 or K3 levels were substituted by simpler synonyms. Each item in the recognition MC task included four choices: the correct adjective and three plausible distracters (three adjectives were either synonymous, contextually relevant or close in meaning). Here is an example:

- It is necessary to pay ........ attention to planning and design to keep the original character of the building.
a. major
b. complete
c. good
d. careful

\section{- Fill in the Blanks}

Active knowledge of vocabulary is associated with speaking and writing on the understanding that learners can retrieve the appropriate written or spoken word form for the meaning they want to express (Nation, 2001). On that basis, fill-in-blanks task (Appendix 4) was treated as active recall task. An additional rationale for using gapfilling questions to practice the learners' controlled productive- active knowledge of lexical units is that gap-filling questions, to a certain degree, resemble real-life communication situations where the learner needs to retrieve words in response to the given contextual clues (Laufer, 1998).

The following is an example of an active recall (Fill-in-blank) task:

- There is a new tennis court, running track and an ....... air swimming pool.

\section{- Translation Tasks}

The other form of the test, that is a free translation task of the same sixteen Arabic 'كسر' 'kasara' 'broke' sentences (Appendix 5 ), was administered to the same participants to explore their proficiency in this linguistic area. The second task was performed prior to the first to avoid any potential post-test effect on the free translation choices of the 


\section{Number 73, Part 2, May, 2016}

participants. The target items are familiar in the Egyptian Arabic dialect. The participants were also asked to translate the ten different written texts used in the MC and Fill in the Blanks test from Arabic into English and vice versa (Appendix 6). Their translations were analyzed, marked, pointed out the interferences, classified them according to their types and were discussed in accordance with the previous literature. The analysis focused on lexical interference which included errors in lexis due to the differences between the two languages; Arabic and English, and the assigned meanings for each word. The translation tasks were included in the two tests used by the participants. One of them comprised English into Arabic translation tasks, and the other included Arabic into English translation tasks. Each of the English /Arabic translation sheets included ten sentences that were adapted from the English/Arabic parallel corpus i.e. some of the sentences were shortened or simplified. The participants were expected to translate the full sentence as they were believed to have an adequate lexical knowledge of $K 2$ and $K 3$. The sentences were checked to be of matching word level. For each sentence, the Lextutor research tool was used to check the words' K-levels. If any of the words in a sentence was not at $K 2$ or maximum $K 3$ level, it was substituted with a synonym that belongs to one of these levels. Here is an example:

- In recent years tourism has made an increasing impact on farming.

The Arabic sentences in the Arabic/ English translation tasks were translations of English sentences adopted from the same parallel corpus and comprised Arabic translations of the target English data. The translations of the target data were also bolded. The following is an example:

يعتقد أن امرأة من كل ستة نسـاء يقعن ضحايا للعنف الأسـري، و لكنهن جميعا يعانين ِِّ

For this research, the test-retest method of measuring instrument reliability was not feasible due to practical issues such as availability of participants, which obstructed the procedure. Nonetheless, the equivalence of forms reliability was ensured since the same exact set of items was used in all tests. As for the rater reliability, the researcher relied on the intra-rater reliability. When scoring the translation tests, only the produced target lexicons were marked as correct, and each correct answer was given one point. Approximately a month later, the researcher re-checked the scoring of all the tests. The tested items, along with their translation, were validated by a jury of specialists to ensure their content and face validity.

\section{9}




\section{Number 73, Part 2, May, 2016}

\section{- Collecting data}

The researcher assigned the participants of thirty five second year students, at Al-Sadat secondary school for girls, Sheblanga, Banha Educational Directorate, Egypt. The participants were from different classes as participation was voluntary, during the recess time, and the data were collected during the second semester 2015/2016. Students were asked to translate different written texts from Arabic into English and vice versa, as well as answering the objective tests; the multiple choices and the Fill in the blanks. Their translations and tests were analyzed, marked, pointed out the lexical interferences, classified according to their types and the communicative strategies that the participants employed. Lexical interference included errors in lexis due to the differences between the two languages, Arabic and English, and the assigned meanings for each word. Since the most important component of word knowledge is the knowledge of the form/ meaning relation, i.e., the ability to retrieve the meaning of a given word form, and the ability to retrieve the word form of a given concept, the translation skill was measured with the recall of meaning, as a passivel receptive knowledge test (E/A translation) and the recall of form $(A / E$ translation) as an active/ productive knowledge test. The transfer errors made by the participants were easily spotted upon examining their translations because the researcher's NL is Arabic, thus simplifying the task of data analysis.

\section{- Scoring English $\rightarrow$ Arabic translation tests}

The translation tests were manually marked by the current researcher. Scoring the English/ Arabic translations of the target lexicons was rather straightforward. The Arabic translation was considered correct by the researcher if the participant was able to understand the meaning of the English word/unit and produced an acceptable translation in the modern Arabic language, according to the intuition of the researcher as a native speaker of Arabic and her strong knowledge of Modern Standard Arabic. If the Arabic translation did not show any understanding or an incorrect understanding of the English lexicons, then the answer was considered wrong. Accordingly, one point was given to each of the acceptable answers, while no point was given for incorrect answers. For example, in translating the opposition 'hard

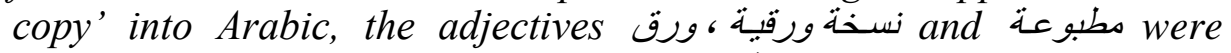
considered acceptable, while the adjective صسبة was considered to be a literal translation of the English vocabulary which does not indicate understanding of meaning. 
Table 3. The Participants' Anomalous and Irrelevant Responses on English into Arabic Translation Task

\begin{tabular}{|c|c|}
\hline English Lexicons & Arabic Translations \\
\hline Common sense & منطق سليم - مشاهد شائعة ششيع محبوب - مشهر شائع \\
\hline Recent years & السنوات القلايمة ـ السنوات الحديثة ـ السنوات الماضية \\
\hline Immediate future & المستقبل الفوري - المستقبل الحالي المبل \\
\hline Domestic violence & العنف الشديا - العنف في المجتمع - العنف الاجتماعي - العنف في الأسرة \\
\hline Hard copy & نسخخ ورقي - نسخ كبيرةً - نسخخ صعبة _- نستخ ورق \\
\hline Round trip & رحلة دائريَة - رحلة كاملة \\
\hline Open air & هواء مفتوح - هواء منعش \\
\hline Vast majority & الأغلبية .......- الغالبية الكبيزة \\
\hline Careful attention & تركيز شُيد _اهتمام كبير \\
\hline Key areas & الأماكن المفتوحة ـ المنطقة المفتوحة ـ مفاتيح الحل \\
\hline
\end{tabular}

In comparison, scoring the Arabicl English tests was less straightforward. This is due to the fact that some of the target lexicons were not highly restricted combinations in Arabic which allowed for a relatively wider range of possible answers. For example, the Arabic collocation 'الغالبينة العظدى' can be translated into different acceptable English collocations other than the desired response 'vast majority'. Some of the produced lexicons which could be accepted collocates are 'great majority' and 'large majority', but not 'big majority', which would be the exact meaning of the collocation in Arabic.

Table 4. The Participants' Anomalous and Irrelevant Responses on Arabic into English Translation Task

\begin{tabular}{|c|c|}
\hline Arabic Text & English Translation \\
\hline السنوات الاخيرة الماضية & Recent - last- last few years - last years ago-recent years \\
\hline منطق بديهي / سليم & $\begin{array}{l}\text { Right thought }- \text { right } \ldots . . .- \text { logic } \ldots . . . \text {-logic logo }- \text { poor } \\
\text { condition }\end{array}$ \\
\hline المستقبل القريب/العاجل & $\begin{array}{l}\text { Nearby future - urgent future - future nearby and urgent- } \\
\text { closer future- near future-future simple }\end{array}$ \\
\hline العنف ألأسري & $\begin{array}{l}\text { Family violence- violence's family - violence of family - } \\
\text { social violence - violence prisoners - violence captives }\end{array}$ \\
\hline نسخ ورقية & Copy paper-paper-sheets - sheet copies \\
\hline رحلة ذهاب و ايـاب & $\begin{array}{l}\text { Go trip and back-go and come-come and back-coming } \\
\text { and return - come and go back-go trip and return - go } \\
\text { and come trip - going and returning trip -complete trip - } \\
\text { trip go and back-go and come back trip - up and down }\end{array}$ \\
\hline الهواء الطلق & fresh \\
\hline الغالبية العظمى & Most of majority - ..... majority \\
\hline اهتمام كبيز & Large interest - big interest- huge interest \\
\hline المجالات الرئيسة & main \\
\hline
\end{tabular}

To ensure the reliability of the scoring process, the researcher rechecked the scores of all passive and active recall tests after an interval of one month, employing the same criteria,. Recruiting a second evaluator for that purpose was an idea taken into consideration; however, it was not feasible due to the abundance of test-papers. 


\section{Number 73, Part 2, May, 2016}

\section{- Data Analysis}

\section{- Quantitative Analysis}

In order to analyze the data obtained for this study quantitatively, it was decided to calculate the frequencies and percentages of the participants' correct responses.. The tests were administered to the participants, and three sets of test scores were gathered and subjected to statistical analyses using SPSS 21 (Statistical Package for the Social Sciences). One set for MC scores, the second one for Fill in Blanks, and the third one for the translation tasks. However, these results cannot be used to make inferences about or assess the strength of the relationship between the independent (causal) variables (NL), and dependent (effect) variables (TL). Therefore, a qualitative analysis of the collected data was a necessity.

\section{- Qualitative Analysis}

It is not precisely clear how the participants made their choices in translating the target lexicons. It is likely that they used various testperforming strategies in order to accomplish the tasks at hand. It could have been that they relied on their NL or made a conjecture, or lost patience or avoided rendering response on purpose, especially when the task was rather difficult. "They might have focused on extraneous factors - say whether the entire sentence was semantically anomalous" (Ellis, 1991). Besides, the participants may have given careless, rather irrelevant responses, created merely to fill in a perceived gap in their vocabulary. Briefly, one cannot claim a single distinctive factor for the participants' choices: several stimuli may work simultaneously to motivate their options. In all cases, nonetheless, the participants must have relied on their implicit and explicit, 'immature' knowledge when generating their communicative utterances in the TL, or on what they assumed to be the TL norms.

\section{- Findings and Discussion}

The first task, the controlled multiple choice lexical translation, was meant to elicit the participants' receptive competence in recognizing the correct English collocations equivalent to the Arabic verb 'كسـر' 'kasara' 'broke'. Some of the participants, 10.4\%, opt for avoiding responding to some items (Table 5)

Data analysis reveals that the overall performance of the participants in the target lexicons is far from being satisfactory. As indicated in Table 6, only $33.6 \%$ of the total attempts of all participants on the objective recognition task of the verb 'كسر' 'kasara' 'broke' were correct. It is worth noticing that some of the responses were really awkward; for example, none of the participants could answer Item 5

\section{2}


correctly, only one out of the 35 participants did respond to Item 8 correctly, only two on Item 13, three on Item 10, four on Item 14, and five on Item 9.

'Table 5. Frequencies and Percentages of the Participants' Responses on 'كسر' 'kasara'

\begin{tabular}{|c|c|c|c|c|c|c|c|c|c|c|}
\hline Item & \multicolumn{5}{|c|}{ Frequency of Responses } & \multicolumn{5}{|c|}{$\%$} \\
\hline & $A$ & $B$ & $C$ & $D$ & Avoidance & $A$ & $B$ & $C$ & $D$ & Avoidance \\
\hline 1 & 15 & 0 & 12 & 3 & 5 & $42.9 \%$ & $0 \%$ & $34.3 \%$ & $8.6 \%$ & $14.3 \%$ \\
\hline 2 & 1 & 8 & 11 & 11 & 4 & $2.9 \%$ & $22.9 \%$ & $31.4 \%$ & $31.4 \%$ & $11.4 \%$ \\
\hline 3 & 2 & 10 & 8 & 11 & 4 & $5.7 \%$ & $28.6 \%$ & $22.9 \%$ & $31.4 \%$ & $11.4 \%$ \\
\hline 4 & 5 & 4 & 0 & 25 & 1 & $14.3 \%$ & $11.4 \%$ & $0 \%$ & $71.4 \%$ & $2.9 \%$ \\
\hline 5 & 0 & 6 & 7 & 14 & 8 & $0 \%$ & $17.1 \%$ & $20 \%$ & $40 \%$ & $22.9 \%$ \\
\hline 6 & 7 & 2 & 24 & 2 & 0 & $20 \%$ & $5.7 \%$ & $68.6 \%$ & $5.7 \%$ & $0 \%$ \\
\hline 7 & 4 & 12 & 0 & 15 & 4 & $11.4 \%$ & $34.3 \%$ & $0 \%$ & $42.9 \%$ & $11.4 \%$ \\
\hline 8 & 14 & 14 & 1 & 2 & 4 & $40 \%$ & $40 \%$ & $2.9 \%$ & $5.7 \%$ & $11.4 \%$ \\
\hline 9 & 8 & 7 & 9 & 5 & 6 & $22.9 \%$ & $20 \%$ & $25.7 \%$ & $14.3 \%$ & $17.1 \%$ \\
\hline 10 & 4 & 11 & 12 & 3 & 5 & $11.4 \%$ & $31.4 \%$ & $34.3 \%$ & $8.6 \%$ & $14.3 \%$ \\
\hline 11 & 14 & 9 & 3 & 8 & 1 & $40 \%$ & $25.7 \%$ & $8.6 \%$ & $22.9 \%$ & $2.9 \%$ \\
\hline 12 & 11 & 18 & 1 & 1 & 4 & $31.4 \%$ & $51.4 \%$ & $2.9 \%$ & $2.9 \%$ & $11.4 \%$ \\
\hline 13 & 10 & 10 & 2 & 8 & 5 & $28.6 \%$ & $28.6 \%$ & $5.7 \%$ & $22.9 \%$ & $14.3 \%$ \\
\hline 14 & 10 & 4 & 4 & 12 & 5 & $28.6 \%$ & $11.4 \%$ & $11.4 \%$ & $34.3 \%$ & $14.3 \%$ \\
\hline 15 & 2 & 29 & 1 & 3 & 0 & $5.7 \%$ & $82.9 \%$ & $2.9 \%$ & $8.6 \%$ & $0 \%$ \\
\hline 16 & 18 & 8 & 4 & 3 & 2 & $51.4 \%$ & $22.9 \%$ & $11.4 \%$ & $8.6 \%$ & $5.7 \%$ \\
\hline \multicolumn{5}{|c|}{ Total Responses $=560$} & 58 & \multicolumn{4}{|c|}{$\%$ of Total Responses $=89.6 \%$} & $\begin{array}{l}\text { \% of Avoidance } \\
\text { Response }=10.4 \%\end{array}$ \\
\hline
\end{tabular}

Table 6. Frequencies and Percentages of the Participants' Correct Responses on the Recognition Test (1)

\begin{tabular}{|c|c|c|c|c|}
\hline $\begin{array}{c}\text { Item } \\
\#\end{array}$ & $\begin{array}{c}\text { No. of Correct } \\
\text { Responses }\end{array}$ & $\begin{array}{c}\text { \% of Correct } \\
\text { Responses }\end{array}$ & $\begin{array}{c}\text { No. of } \\
\text { Avoidances }\end{array}$ & $\begin{array}{c}\text { \% of } \\
\text { Avoidance }\end{array}$ \\
\hline 1 & 15 & $42.9 \%$ & 5 & $14.3 \%$ \\
\hline 2 & 11 & $31.4 \%$ & 4 & $11.4 \%$ \\
\hline 3 & 11 & $32.4 \%$ & 4 & $11.4 \%$ \\
\hline 4 & 25 & $73.5 \%$ & 1 & $2.9 \%$ \\
\hline 5 & 0 & $0 \%$ & 8 & $22.9 \%$ \\
\hline 6 & 24 & $68.6 \%$ & 0 & $0 \%$ \\
\hline 7 & 12 & $35.3 \%$ & 4 & $11.4 \%$ \\
\hline 8 & 1 & $2.9 \%$ & 4 & $11.4 \%$ \\
\hline 9 & 5 & 14.7 & 6 & $17.1 \%$ \\
\hline 10 & 3 & $8.6 \%$ & 5 & $14.3 \%$ \\
\hline 11 & 14 & $41.2 \%$ & 1 & $2.9 \%$ \\
\hline 12 & 11 & $32.4 \%$ & 4 & $11.4 \%$ \\
\hline 13 & 2 & $6.1 \%$ & 5 & $14.3 \%$ \\
\hline 14 & 4 & $12.1 \%$ & 5 & $14.3 \%$ \\
\hline 15 & 29 & $82.9 \%$ & 0 & $0 \%$ \\
\hline 16 & 18 & $51.4 \%$ & 2 & $5.7 \%$ \\
\hline Total & 185 & $33.6 \%$ & 58 & $10.4 \%$ \\
\hline
\end{tabular}




\section{Number 73, Part 2, May, 2016}

The second MC test that contains ten items testing the target set of lexical units that were used to test the participants' receptive skill in recognizing the correct English appositions. The results showed that $64 \%$ of the participants came out with the correct responses (Table 7).

Table 7. Frequencies and Percentages of the Participants' Correct Responses on the Recognition Test (2)

\begin{tabular}{|c|c|c|c|c|}
\hline $\begin{array}{c}\text { Item } \\
\#\end{array}$ & $\begin{array}{c}\text { No. of Correct } \\
\text { Responses }\end{array}$ & $\begin{array}{c}\text { \% of Correct } \\
\text { Responses }\end{array}$ & $\begin{array}{c}\text { No. of } \\
\text { Avoidances }\end{array}$ & $\begin{array}{c}\text { \% of } \\
\text { Avoidance }\end{array}$ \\
\hline 1 & 18 & $57.6 \%$ & 3 & $8.6 \%$ \\
\hline 2 & 28 & $84.8 \%$ & 1 & $2.9 \%$ \\
\hline 3 & 22 & $66.7 \%$ & 2 & $5.7 \%$ \\
\hline 4 & 25 & $75.8 \%$ & 1 & $2.9 \%$ \\
\hline 5 & 22 & $66.7 \%$ & 4 & $11.4 \%$ \\
\hline 6 & 22 & $66.7 \%$ & 5 & $14.3 \%$ \\
\hline 7 & 24 & $72.7 \%$ & 1 & $2.9 \%$ \\
\hline 8 & 24 & $72.7 \%$ & 3 & $8.6 \%$ \\
\hline 9 & 19 & $57.6 \%$ & 4 & $11.4 \%$ \\
\hline 10 & 20 & $60.6 \%$ & 5 & $14.3 \%$ \\
\hline Total & 224 & $64 \%$ & 29 & $8.3 \%$ \\
\hline
\end{tabular}

The results of the productive test (Fill in the Blanks), in Table 8, manifested that the correct responses of all participants in all tested lexical units did not even reach half of the total responses (46\%). These results signified that the results on the productive test were worse than that the receptive one (MC, 64\%, Table 7), which seem to be easier for the participants, on the same tested lexical units.

Table 8. Frequencies and Percentages of the Participants' Correct Responses on the Productive Test 1 (Fill in the Blanks) in English

\begin{tabular}{|c|c|c|c|c|}
\hline Item \# & $\begin{array}{c}\text { No. of Correct } \\
\text { Responses }\end{array}$ & $\begin{array}{c}\text { \% of Correct } \\
\text { Responses }\end{array}$ & Avoidance & $\%$ \\
\hline 1 & 24 & $72.7 \%$ & 1 & $2.9 \%$ \\
\hline 2 & 13 & $39.4 \%$ & 8 & $22.9 \%$ \\
\hline 3 & 9 & $27.3 \%$ & 7 & $20 \%$ \\
\hline 4 & 11 & $33.3 \%$ & 4 & $11.4 \%$ \\
\hline 5 & 16 & $48.5 \%$ & 6 & $17.1 \%$ \\
\hline 6 & 17 & $51.5 \%$ & 5 & $14.3 \%$ \\
\hline 7 & 25 & $75.8 \%$ & 4 & $11.4 \%$ \\
\hline 8 & 23 & $69.7 \%$ & 3 & $8.6 \%$ \\
\hline 9 & 9 & $27.3 \%$ & 7 & $20 \%$ \\
\hline 10 & 14 & $42.4 \%$ & 5 & $14.3 \%$ \\
\hline Total & 161 & $46 \%$ & 50 & $14.3 \%$ \\
\hline
\end{tabular}

The second set of tests, including the Fill in the Blanks and the free translation of the same Arabic lexical units, were intended to explore the same participants' productive proficiency in this linguistic phenomenon. Both tasks, the receptive and the productive ones, are viewed as indicators of the participants' proficiency in this TL area. As 
for the free translation task, only $34.6 \%$ of the total attempts of the participants in translation from English to Arabic were correct (Table 9).

Table 9. Percentages of the Participants' Correct Responses on the Productive Test (Free Translation) from English into Arabic

\begin{tabular}{|c|c|c|}
\hline English Lexicons & $\begin{array}{c}\text { Number of Correct Arabic } \\
\text { Translation }\end{array}$ & $\begin{array}{c}\text { \% of Correct Arabic } \\
\text { Translation }\end{array}$ \\
\hline Common sense & 15 & $42.9 \%$ \\
\hline Recent years & 12 & $34.3 \%$ \\
\hline Immediate future & 16 & $45.7 \%$ \\
\hline Domestic violence & 10 & $28.6 \%$ \\
\hline Hard copy & 8 & $22.9 \%$ \\
\hline Round trip & 15 & $42.9 \%$ \\
\hline Open air & 18 & $51.4 \%$ \\
\hline Vast majority & 13 & $37.1 \%$ \\
\hline Careful attention & 9 & $25.7 \%$ \\
\hline Key areas & 5 & $14.3 \%$ \\
\hline Total & 121 & $34.6 \%$ \\
\hline
\end{tabular}

Meanwhile, the results on the productive, free translation task from Arabic into English were even worse; only $24.6 \%$ of the participants' total attempts in this task were correct, as indicated in Table 10. In addition, surprisingly an observable percentage $(2.9 \%)$ of the participants' responses on the free translation task came out with irrelevant responses or meaningless utterances or message substitution (Table 3 and 4), which may have been triggered by an unconscious reference to $N L$ or wrong interpretation of the target lexical units. The influence of fatigue, lack of concentration or carelessness while performing the task cannot be overlooked.

Table 10. Percentages of the Participants' Correct Responses on the Productive Test (Free Translation) from Arabic into English

\begin{tabular}{|c|c|c|}
\hline $\begin{array}{c}\text { Arabic Source data } \\
\text { (Input) }\end{array}$ & $\begin{array}{l}\text { Number of Correct } \\
\text { English Translation }\end{array}$ & $\begin{array}{c}\text { \% of Correct English } \\
\text { Translation }\end{array}$ \\
\hline السنوات الاخيرة" الماضية & 10 & $28.6 \%$ \\
\hline منطق بايهي/سليم " & 12 & $34.3 \%$ \\
\hline المستقبل القريب/العاجل & 11 & $31.4 \%$ \\
\hline العنف ألاسري & 8 & $22.9 \%$ \\
\hline نسخ ورقية & 5 & $14.3 \%$ \\
\hline رحلة ذهاب و اياب & 7 & $20 \%$ \\
\hline الههواء الطلق & 14 & $40 \%$ \\
\hline الغالبية العظمى & 8 & $22.9 \%$ \\
\hline اهتمام كبيز & 7 & $20 \%$ \\
\hline المجالات الرئيسة & 4 & $11.4 \%$ \\
\hline Total & 86 & $24.6 \%$ \\
\hline
\end{tabular}

- Contributing Factors to Linguistic Transfer 
Hopkinson (2007) divides three key factors that contribute to language interference.

\section{- Inadequate Reference Materials}

\section{a) Segmentation of Semantic Field}

According to Hopkinson (2007), segmentation of semantic field occurs when translators rely on the meaning of a word in dictionary and do not consider wider context of the word.

For example:

- kusirat shawkata l.9aduww (source language)

- The enemy's fork was broken

- The enemy's power was eliminated (participants' translation) (correct translation)

b) Exact Syntactic Equivalence in Lexical Interference

This occurs when "the source text expresses a concept by using a particular word or expression, but learners frequently attempt to produce the exact equivalent word/ lexicon in the target text" (Hopkinson, 2007). Here, EFL learners need to express the word of source text in specific lexicon (collocation) of the target language, but some of them fail to do this and attempt to find the exact word translation which is incorrect.

For example:

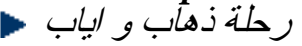

- Going and returning trip

- Round trip

- Generalization from false hypotheses

a) Lexical Generalization: False Cognates

At the lexical level, "this tendency to the generalization leads to the occurrence of false cognates, colloquially termed false friends" (Hopkinson2007).

For example:

- yami:n

- Right hand

- Oath or vow

(source text)

(participants' translation)

(correct translation)

\section{b) Generalization in Word-Formation}

Hopkinson (2007) asserts that one area which is particularly affected by this factor is that noun suffixes. In many cases and contexts this transformational rule is valid (e.g. 'nusakh waraqueya' نسخخورقية = paper copies), but in some cases it leads to the occurrence of generalization in word formation ('nusakh waraqueya' نسخخورقية paper copying). 


\section{- Systemic and structural differences}

\section{a) Morphological System}

According to Hopkinson (2007), morphological system affects language interference on the level of word-formation, especially the transformation of verbs into nouns and of nouns into verbs. For example:

كسر بعض العدال الاضراب و عادوا اللعدل

- Some workers broke the striking and returned to work (the participants' translation)

Some workers broke the strike and returned to work. (correct translation)

\section{b) Syntactical System}

According to Hopkinson (2007), syntactical system affects language interference mostly on the level of word order.

\section{For example:}

\section{- كسر أنف خصده فأرغده على المواققة على ما بريا kasara ?anf xaSmih} (source language)

- He broke his opponent's nose, so he forced him to give into what he wanted. (The participants' translation)

- He humiliated his opponent, forcing him to give into what he wanted.(correct translation)

Lott (1983) also divides three factors that contribute to language interference. They are over extension of analogy, transfer of structure, and interlingual factors: overextension of analogy that includes orthographic, semantic and syntactic. According to him, orthographic affects the occurrence of language interference on the level of cognate words. For example, the Arabic word

'بين is used to mean 'oath' in English, but because of the orthographic similarities of Arabic word 'يبنين' which does mean 'right', the deviation took place. The semantic, as well, affects the occurrence of language interference on the level of semantic field. For example, the English word 'key' is used to mean 'main', because of the wider semantic reference of it. The Arabic word 'حفت ' $ح$ ' 'mufta7' which can be used for both 'a key' in general and 'main' in particular. Lott (1983) also claims that syntactic affects the occurrence of language interference on the level of word category or word class. For example, the English word 'open' is used as a noun, a verb, and an adjective. The correct Arabic translation is 'طلق' 'talq' which occurs as both an adjective and a noun. According to Lott (1983), lexical distinction occurs because it does not exist in the source language. For example, in English there is a lexical distinction between the word 'make' and 'do'. On the other hand, in Arabic language the lexical distinction does not exist and both 'make/do' will be translated into 'عل' 'a 'mal'. 


\section{Number 73, Part 2, May, 2016}

\section{- Used Communicative Strategies}

On another level, the researcher tried to go further and deeper into the qualitative analysis of the collected data and identified some communicative strategies that the participants employed when translating Arabic into English.

Qualitative data analysis has identified some distinct communicative strategies manipulated by the participants when translating Arabic texts into English. They are defined as "compensatory strategies that the participants might have used to express their interpretation of the meaning when faced with some difficulty", or "techniques of coping with difficulties in communicating" (Stern, 1983). The quantitative analysis of this research paid particular attention to specific strategies; including avoidance strategy and compensatory strategies; literal translation, paraphrase, substitution, overgeneralization, use of assumed synonyms, and graphic ambiguity. These will be briefly displayed and exemplified below.

\section{- Avoidance}

It is one of the common strategies employed by FL learners in the production of the TL when they have inadequate and/or incomplete knowledge about the lexical items. The researcher observed that some the participants refrained from carrying out the assigned task on the grounds that they perceived it to be difficult or time-consuming or they just felt no guts to be tested, i.e. task complete avoidance. In our data, it is not clear whether the participants' avoidance was due to their proficiency level or lack of determination or concentration. The participants avoided giving response to certain items; item abandonment, in the objective tasks, i.e., multiple choices (total avoidance ranges from $8.3 \%$ to $10.4 \%$ ) while they avoided responding to some others in the production tasks, i.e., Fill in the blanks (total avoidance $14.4 \%$ ) and free translation the percentage was higher (total avoidance $21.6 \%$ ) of the total attempts. They either leave it unfinished because of its difficulty or avoid it completely. To account for this high percentage of avoidance, the researcher put into consideration the hypothesis that some of the participants were impatient and plausibly unwilling to continue a voluntary test.

\section{- Literal Translation}

The current research suggests unmistakable evidence for the role of the $N L$ in the acquisition of the TL. Learners tend to manipulate their $N L$ in their TL production whenever they do not have the adequate knowledge of the relevant TL form to be used. Literal translation strategy accounts for (25.7\%) of the participants' potential attempts in Fill in the Blanks, whereas (34.3\%) of the free translation task. 
The findings of the present study endorse, though partially, some of those in the previous literature on the role of the NL. The Arabic verb ' 'كسر 'kasara' broke have equivalents in English. Surprisingly, however, many of the participants failed to produce the equivalent forms, perhaps conceiving them as Arabic-specific. Examples of literal translation cited from both tasks are:

Table 11

\begin{tabular}{|c|c|c|c|}
\hline 3 & $\begin{array}{l}\text { He broke his opponent's } \\
\text { nose. }\end{array}$ & $\begin{array}{l}\text { كسر أنف خصمه } \\
\text { kasara ?anf xasmih }\end{array}$ & humiliated his opponent \\
\hline 4 & $\begin{array}{l}\text { The enemy's thorn/fork was } \\
\text { crushed/ broken . }\end{array}$ & $\begin{array}{l}\text { كسرت شوكة العدو } \\
\text { kusirat shawkat al.9aduww }\end{array}$ & power was eliminated \\
\hline 15 & $\begin{array}{l}\text { The enemy broke in the } \\
\text { battle. }\end{array}$ & $\begin{array}{l}\text { انكسر العدو في المعركة } \\
\text { Inkasar al.9aduww }\end{array}$ & was defeated \\
\hline 8 & $\begin{array}{l}\text { He broke his thirst with } \\
\text { cold juice. }\end{array}$ & $\begin{array}{l}\text { كسر عطشه بالعصير البارد } \\
\text { kasara9aTashahu }\end{array}$ & quenched thirst \\
\hline 7 & $\begin{array}{l}\text { I broke my fast a moment } \\
\text { ago. }\end{array}$ & $\begin{array}{l}\text { كسرت صيامي قبل قليل } \\
\text { Kasartu seyamy }\end{array}$ & had breakfast \\
\hline 2 & He broke the wall of silence. & $\begin{array}{l}\text { كسر جدار الصمت } \\
\text { kasara gedaar as.samt }\end{array}$ & broke silence \\
\hline 12 & Sun rays break in water. & $\begin{array}{l}\text { تنكسر أُشعة الثمس في الماء } \\
\text { tankaser ?shea'at eshams }\end{array}$ & sun rays refract \\
\hline
\end{tabular}

The above examples clearly show literal translation of 'كسر 'broke'. However, 'broke' in these utterances indicate meanings different from those intended by the original Arabic 'كسر' 'kasara'. In (13), the lexical sequence كسر أنف خصده kasara ?anf xasmih is viewed as an obvious cultural transfer, since أنف 'nose'? nf is taken to be the symbol of pride and dignity in Arabic. Similarly in (4) some participants translated 'شوكة ' shawkat in 'kusirat shawkat al.9aduww كسرت شوكة العدو' by the word 'thorn' and 'fork', respectively--a synonym that is unlikely in the given English context, though the Arabic translation provides a metaphorical sense to the effect that شوكة Symbolizes 'power'.

Following are examples of literal translation, paraphrase, substitution, overgeneralization, use of assumed synonyms, and graphic ambiguity from the ten lexical units set:

Table 12: Occurrences of communicative strategies in Responses on the Productive Test (Free Translation) from Arabic into

\begin{tabular}{|c|c|c|}
\hline $\begin{array}{c}\text { ARABIC } \\
\text { TEXT }\end{array}$ & ENGLISH TRANSLATION & $\begin{array}{c}\text { COMMUNICATIVE } \\
\text { STRATEGIES }\end{array}$ \\
\hline الماضـــة ات الأخيـــرة & $\begin{array}{l}\text { Recent-last- last few years } \\
- \text { last years ago -recent } \\
\text { years }\end{array}$ & $\begin{array}{l}\text { Literal translation } \\
\text { overgeneralization }\end{array}$ \\
\hline منطق بـ اهي / سليم & $\begin{array}{l}\text { Right thought }- \text { right ....- } \\
\text { logic ...... -logic logo - } \\
\text { poor condition }\end{array}$ & $\begin{array}{l}\begin{array}{l}\text { Literal translation }- \text { irrelevant } \\
\text { responses } \\
\text { responses }\end{array}-\quad \text { meaningless } \\
\end{array}$ \\
\hline
\end{tabular}


Number 73, Part 2, May, 2016

\begin{tabular}{|c|c|c|}
\hline العسجــتبل القريسـب / المسبـ & $\begin{array}{l}\text { Nearby future - urgent } \\
\text { future - future nearby and } \\
\text { urgent- closer future- near } \\
\text { future-future simple }\end{array}$ & $\begin{array}{l}\text { Literal translation - assumed } \\
\text { synonyms - paraphrase }\end{array}$ \\
\hline العنف ألأسري & $\begin{array}{l}\text { Family violence- violence's } \\
\text { family - violence of family - } \\
\text { social violence - violence } \\
\text { prisoners - violence } \\
\text { captives }\end{array}$ & $\begin{array}{l}\text { Literal translation - assumed } \\
\text { synonyms - graphic ambiguity }\end{array}$ \\
\hline نسخ ورقية & $\begin{array}{l}\text { Copy paper - paper- sheets } \\
\text { - sheet copies }\end{array}$ & $\begin{array}{l}\text { Literal translation - assumed } \\
\text { synonyms - overgeneralization }\end{array}$ \\
\hline رحلة ذهاب وايـاب & $\begin{array}{l}\text { Go trip and back - go and } \\
\text { come - come and back - } \\
\text { coming and return - come } \\
\text { and go back - go trip and } \\
\text { return - go and come trip - } \\
\text { going and returning trip - } \\
\text { complete trip - trip go and } \\
\text { back - go and come back } \\
\text { trip-up and down }\end{array}$ & $\begin{array}{l}\text { Paraphrase-literal translation- } \\
\text { overgeneralization }\end{array}$ \\
\hline الهواء الطلق & fresh & Assumed synonyms \\
\hline الغالبية العظمى & $\begin{array}{l}\text { Most of majority }-\ldots . . . \\
\text { majority }\end{array}$ & avoidance \\
\hline اهتمام كبيز & $\begin{array}{l}\text { Large interest-big interest- } \\
\text { huge interest }\end{array}$ & $\begin{array}{l}\text { Assumed synonyms Literal } \\
\text { translation }\end{array}$ \\
\hline المجالات الرئيسة & main & Literal translation \\
\hline
\end{tabular}

- Paraphrase

When learners fail to translate idiomatically due to a deficiency in their lexical knowledge, they often resort to paraphrase to convey the intended message. More often learners miss certain essential semantic aspects of the message or produce fragmented sentences which sound inappropriate by the TL norms. Paraphrase was the most frequently used by the participants (28.6\%). Following are some examples:

1. She disobeyed her husband's order.

2. He stopped the prevailing silence.

5. His death caused the army to lose their morality.

7. He ate a minute ago.

8. He stopped his thirst by juice.

9. He made the taste of the medicine bitter.

14. The irrevocable debts made him lose his money.

- Substitution

Failing to produce the proper lexical item, the learners look for a substitute term that shares semantic properties with it. In the collected data, many participants' incorrect substitutions are traceable to $N L$ transfer or paraphrase. A substantial ratio of the participants' errors (17.1\%) incurred by inappropriate substitution. Illustrative examples are: 
9. He lightened/lessened/crushed/diluted the bitterness of the medicine with...

13. The waves shattered on the shore rocks.

2. He violated / cut / interrupted / distracted the prevailing silence.

6. He cracked her heart.

5. His death cut down / cancelled the army's spirits.

1. She flouted / put down her husband's oath.

11. The police penetrated / violated the law when...

In (1), the substitute verb 'flout' colored the intended message with the sense of rebellion (i.e. broke his oath). In (13), apparently, the participants substituted 'كسـر' by a 'remote synonym', i.e., 'بدر' 'baddada' and, mistakenly, used its English equivalent 'shattered' to occur with 'the waves'. Likewise, in (3 and 11) the participants must have interpreted it in the original statements as 'intahaka / qaTa9a / qa:Ta9a /baddada / ixtaraqa' all sharing certain common semantic features of 'kasara' كسر 'broke'.

\section{- Overgeneralization}

Overgeneralization and analogy are communication strategies in which a certain TL form is expanded to a different contextual use in the $T L$. This strategy does not form a high ratio of the participants' overall responses, only (2.9\%). Some examples are:

13. The waves refracted on the shore rock.

14. The irrevocable debts defeated him,

8. He wetted/extinguished his thirst with cold juice.

11. The police ashamed the law when they arrested the MP's.

In (14) the participants extended the meaning of انكسر العدو in كسر 'The enemy was defeated' to كسرته الديون' 'kasarathu ad.diyu:n'. The debts broke him', then substituted defeated for 'broke' by analogy. In

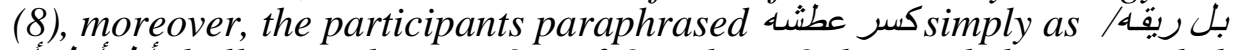
أطفأ ظدأ. 'balla ri:qahu' or '?aTafa? a Thama?ahu' and then extended the translation of this interpretation into English, namely wetted/extinguished his thirst. In (11), furthermore, the participants seem to have confused the verb shamed and the adjective ashamed in their interpretation of 'كسـرت الثـرطة القانون 'kasarat ash.shurtatu al.qa:nu:n', the police broke the law' and replaced 'broke' with 'ashamed'.

\section{- Assumed Synonyms}

When the participants were short of the appropriate translation, they look for a synonym or a near-synonym in the TL, the result is erroneous translation.The use of assumed synonyms comprised only (2.9\%) of the participants' responses. Examples are: 


\section{Number 73, Part 2, May, 2016}

6. He cracked / shattered her heart.

10. Some workers interrupted / violated the strike.

14. The irrevocable debts failed/defeated him.

15. The enemy was failed in the battle.

Obviously, the participants used the main verbs in the above sentences as synonyms for defeated (15) and broke in (14, 10 and 6) respectively, on the assumption that they are semantically equivalent.

\section{- Graphic Ambiguity}

The participants' responses demonstrate a small but interesting ratio (2.9\%) of a special type of error which might have been initiated by the ambiguity of certain words as inspired by a biased reading of the Arabic text that might have risen from the Arabic orthographical script. Such errors may be characterized as graphic. Following are some examples:

1. She broke her husband's right بين arm

- Captives'violence / prisoners'violence العنف الأسرين

Sentence (1) manifests a partial reading of the intended Arabic meaning. Apparently, some participants read بين 'oath' which is intended by the Arabic sentence as 'right arm' a far-fetched meaning implied in the Arabic core word يمين but the context makes this reading unlikely. A few of the participants were misled by the orthographic confusion caused by the word 'أسرى" and 'أسري".

\section{- Conclusion}

The results of the study demonstrated that the Egyptian secondary stage students have difficulty with English/Arabic translation as well as Arabic/English one. Their overall proficiency in this linguistic area was found to be inadequate. The results showed that negative transfer / interference has clearly affected the translation of the students when they attempted to translate text from Arabic into English and vice versa. Participants' proficiency in the recognition, receptive task was significantly better than in the productive task. The most frequent interference that transpired in the target tasks was the lexical and semantic ones. The qualitative analysis of the data manifested that linguistic interference occurred due to some factors that contributed to its occurrence. The participants employed some communicative strategies to compensate for their inadequate proficiency in translation. Those strategies have been identified, exemplified, and described. Most of the results inaugurated in this study go in line with the review of literature and match the results of previous researches which indicate that the problem of linguistic transfer/interference can be considered as a global problem. Considering that the previous researches investigated

\section{2}




\section{Number 73, Part 2, May, 2016}

different languages, it was clearly proven that every language has its own set of rules and lexis and even if the NL share some features with the TL, interference still affects both languages. On the whole, the findings of the study have subscribed to the role of the NL in TL proficiency, suggesting the need for a more constructive instructional focus on translation starting at the school level and raising the importance of the phenomenon of transfer from NL to TL.

The researcher suggests that EFL learners need to read, learn, and practice a lot of words or structures in order that they are able to easily recognize and avoid the linguistic interference. Even if they cannot avoid it, they, at least, can minimize its occurrence. Teachers should keep monitoring their students' development by giving a prompt evaluation and feedback to them. Therefore, they can help their students realize the problems that they may encounter during translation class.

By understanding the students' problem, the teachers will be able to vary the learning materials that contain language interference and create new teaching techniques in the translation class. The study of linguistic transfer needs further research to benefit the teachers, students, and other pedagogists.

\section{- $\underline{\text { References }}$}

- AbiSamra, N. (2003). An analysis of errors in Arabic speakers' English writings, Ph.D. dissertation. Beirut :American university.

- Ali, N. (2007). Some linguistic problems facing Arab learners of English. Adab Al- Rafidayn. (48), 1-14.

- Al-Najjar, M.F. (1984). Translation as a Correlative of Meaning: Cultural and Linguistic Transfer between Arabic and English. Ph.D. dissertation. USA: Indiana University.

- Bahameed, A.S., (2008). Cultural Hindrances in Arabic-English Translation. Translation Journal, 12(1).

- Bartlet, H. (1983). Transfer and variability of rhetorical redundancy in Apachean English interlanguages. In: S. Gass \& Selinker (eds.) Language transfer in language learning. Rowley, MA: Newbury House.

- Ben-Osman, M. (2005). Translation equivalence of literary language between Arabic and English. Ph.D. dissertation, England: University of Manchester.

- Bhela, B. (1999). Native language Interference in learning a second language: exploratory case studies of native language interference with target language usage. International Education Journal 1, (1).

- Bloem, I., Bogaard, S., \& La Heij, W. (2004). Semantic facilitation and semantic interference in language production: Further evidence

\section{3}

Journal of Arabic Studies in Fdıcation \& Psychology (ASEP) 


\section{Number 73, Part 2, May, 2016}

for the conceptual selection model of lexical access. Journal of Memory and Language, 51, 307-323.

- Brown, H. (2007). Principles of language learning and teaching. (5th Ed.). New Jersey: Pearson Educated Limited.

- Buainain, H. (2010). Researching types and causes of errors in Arabic speakers' writings. Ph.D. dissertation, Qatar University.

- Carreres, A. (2006). Strange Bedfellows: Translation and Language Teaching. The Teaching of Translation into L2 in Modern Languages Degrees: Uses and Limitations.Paper presented at the 6 th Symposium on Translation, Terminology and Interpretation in Cuba and Canada. Canadian Translators,Terminologists and Interpreters Council.

- Corder, S. (1967). The significance of learners' errors. Reprinted in J.C.Richards (ed.)(1974, 1984) Error Analysis: Perspectives on Second Language Acquisition. London: Longman,19- 27(Originally in International Review of Applied Linguistics, 5 (4) , 160-170.)

- Corder, S. P. (1977). A role for the mother tongue. In S. M. Gass \& L. Selinker (Eds.),Language transfer in language learning. Amsterdam, NL: John Benjamins Publishing, 18-31.

- Diab, N. (1996). The transfer of Arabic in the English writings of Lebanese Students. ESP, Sao Paulo, 18, (1) 71-83.

- Dweik, B. (2013). Translating cultural and literary expressions from English into Arabic. Sayyab Translation Journal, 5, 57-70.

- Ellis, N. C. (1997). Vocabulary acquisition: Word structure, collocation, word- class, and meaning, in Schmitt, N., and McCarthy, M. (eds.) Vocabulary: Description, acquisition and pedagogy. Cambridge: Cambridge University Press, 122-139.

- Ellis, N. C. (2006). Selective attention and transfer Phenomena in L2 acquisition: Contingency, cue Competition, salience, interference, overshadowing, blocking, and perceptual learning. Applied Linguistics, 27(2), 164-194.

- Ellis, N. C. (2008). Words and their usage: Commentary on the special issue on the bilingual mental lexicon. The Mental Lexicon, 3(3), 375-385.

- Erarslan, A. \& Hol, D. (2014). Language interference on English: Transfer on the vocabulary, tense and preposition use of freshmen Turkish EFL learners. ELTA Journal, 2 (2) 4-22.

- Fakhri, A. (1994). Text organization and transfer. IRAL, XXXII (1).

- Farghal, M. (1995). Lexical and discoursal problems in EnglishArabic translation. Meta: Journal Des Traducteurs/Meta: Translators' Journal, 40(1), 54-61. 
- Farghal, M. \& Shunnaq, A. (1992). Major problems in students' translations of English legal texts into Arabic. Babel, 38(4), 203-210.

- Faris, A. \& Sahu, R. (2013). The translation of English collocations into Arabic: Problems and solutions. Adab Al-Basrah, (64), 51-66.

- Gaber, J. (2005). A textbook of translation: Concept, Method and practice. Al-Ain, UAE: University Book House.

- Galvao, G. (2009). Linguistic interference in translated academic texts. Sweden: Vaxjo University.

- Goundareva, I. (2011). Effect of translation practice on vocabulary acquisition in L2 Spanish. Working Papers of the Linguistics Circle of the University of Victoria, 21, 145-154.

- Havlaskova, Z. (2010).Interference in students' translation. Unpublished M.A. Thesis, Brno, Czech Republic: Masaryk University.

- Hopkinson, C. 2007. Factors in Linguistic Interference: A Case Study in

- Translation. In SKASE Journal of Translation and Interpretation, 2 (1), 13-23.

- James, C. (1998). Errors in Language Learning and Use: Exploring Error Analysis. Pearson Education Limited, London.

- Jarvis, S. (2000). Methodological rigor in the study of transfer: Identifying L1 influence in the interlanguage lexicon. Language Learning, 50(2), 245-309.

- Jarvis, S. \& Pavlenko, A. (2008). Cross linguistic influence in language and cognition. New York, US: Routledge.

- Jarvis, S. (2009) Lexical transfer, in Pavlenko, A. (ed.) The Bilingual Mental Lexicon Interdisciplinary Approaches. Cromwell Press Ltd, pp. 99-124.

- Jiang, N. (2000). 'Lexical representation and development in a second language', Applied Linguistics, 21, 47-77.

- Jiang, N. (2002). 'Form-meaning mapping in vocabulary acquisition in a second language', Studies in Second Language Acquisition, 24, 617-637.

- Jiang, N. (2004). 'Semantic transfer and its implications for vocabulary teaching in a second language', The Modern Language Journal, 24, 416-432.

- Jie, X. (2008). Error theories and second language acquisition. USChina foreign language, 6(1), 35-42.

- Kasper, G. (1992). Pragmatic transfer. Second Language Research, 8 (3), 232-250. 


\section{Number 73, Part 2, May, 2016}

- Khalil, A. (1993). Arabic translation of English passive sentences: Problems and acceptability judgments. Papers and studies in contrastive linguistics, 27, 169-181.

- Kiraly, C. (1995). Pathways to translation: Pedagogy and process. Kent, OH: The Kent State University Press.

- Lado, R. (1964). Language teaching: a scientific approach. New York: McGraw Hill Inc.

- Laufer, B. (1998). The development of passive and active vocabulary in a second language: same or different?, Applied Linguistics, 19 (2), 255-271.

- Laufer, B., and Goldstein, Z. (2004). Testing vocabulary knowledge: size, strength and computer adaptiveness. Language Learning, 54 (3), 399-436.

- Li, D. (2006). Making translation testing more teaching-oriented: A case study of translation testing in China. Meta, 51(1), 72-88.

- Lott, D. 1983. Analyzing and counteracting interference errors. ELT Journal, 37(3), 256- 261.

- Maros, M., Hua, T., \& Salehuddin, K. (2007). Interference in learning English: Grammatical errors in English essay writing among rural Malay secondary school students in Malaysia. E- Bangi, Journal of Social Sciences and Humanities, 2 (2) 1-15.

- Mehdi, M. (1981). The interference of Arabic in the use of English prepositions. Ph.D. dissertation, Austin: University of Texas.

- Mitchell, R., \& Myles, F. (2004). Second language learning theories (2nd Ed). London UK: Hodder Arnold.

- Mouakket, M. (1986). Linguistics and translation: some semantic problems in Arabic-English translation. Ph.D. dissertation, Washington, D.C.: Georgetown University.

- Naimushin, B. (2002). Translation in foreign language teaching: The fifth skill. Modern English Teacher. 11(4), 46-49.

- Nation,P. (2001).The role of the first language in foreign language learning. Asian EFL Journals, 32(3), 177-175.

- Nation, I. S. P. (2001) Learning vocabulary in another language. Cambridge: UK Cambridge University press.

- Neumeier, P. (2005). A closer look at blended learning - parameters for designing a blended learning environment for language teaching and learning. ReCALL, 17(2), 163-178.

- Newmark, P. (1988). A textbook in translation. Hardford- shire: Prentice Hall. 


\section{Number 73, Part 2, May, 2016}

- Norrish, J. (1992). Language learners and their errors. London: Macmillan Publishers.

- Odlin, T. (1989).Language transfer: cross-linguistic influence in language learning.Cambridge:Cambridge University Press.

- Oldin, T. (1992). Transferability and linguistic substrates. Second Language Research, 8 (3), 171-202.

- Odlin, T. (2003). Cross-linguistic influence. In: C. Doughty and M. Long (eds.), The handbook of second language acquisition. Malden, MA: Blackwell, 436-486.

- SattiHamad, M.,\& Yassin, A. (2015). Investigating lexical errors and their effect on university students' written performance in Sudan. SUST Journal of Humanities, 16, (1) 1-18.

- Schmitt, N., Schmitt, D., and Clapham, C. (2001). Developing and exploring the behaviour of two new versions of the Vocabulary Levels Test, Language Testing, 18, 55-88.

- Scott, M. \& R. Tucker. (1974). Error analysis and English language strategies of Arab students. Language Learning, 24, 69-97.

- Sridhar, S. (1980). Contrastive analysis, error analysis, and interlanguage. IN: J. Fisiak (ed.) Contrastive linguistics and the language teacher. Oxford: Pergamon Press.

- Stern, H. (1983). Fundamental Concepts of Language Teaching. Oxford: Oxford University Press.

- Takala, S. (1984). Evaluation of Students' knowledge of Vocabulary in the Finnish Comprehensive School (Reports of the Institute of Educational Research, No. 350). Finland: Jyväskylä.

- Thawabteh, M. (2011). Linguistic, cultural and technical problems in English- Arabic subtitling. SKASE Journal of Translation and Interpretation, 5(1).

- Vannestal, M. (2009). Linguistic interference in translated academic texts: A case study of Portuguese interference in abstract translated into English. Sweden: Linnaeus University.

- Zreg, M. M. (1983). Identification of specific Arabic language interference problems and their effect on the learning of English structure. Ph.D. dissertation, USA: University of Kansas.

- Zughoul, M. (1973).Teaching English Prepositions to Arab Students. Unpublished MA Thesis, American University of Beirut.

- Zughoul, M \& Abdel-Fattah, H. (2003). Collocational strategies of Arab learners of English: A study of lexical semantics, ERIC.

潘溇潾潾洸 
